\title{
GEBYAR KESEHATAN SEBAGAI BENTUK UPAYA PROMOTIF UNTUK MENCEGAH PENINGKATAN FAKTOR RESIKO PENYAKIT TIDAK MENULAR DI DESA SIRNAGALIH WILAYAH KERJA PUSKESMAS CISURUPAN KABUPATEN GARUT TAHUN 2019
}

\author{
Tantri Puspita ${ }^{1}$, Muhammad Hadi Sulhan ${ }^{2}$, Susan Susyanti ${ }^{3}$, Iin Patimah ${ }^{4}$, Wahyudin ${ }^{5}$, \\ Hasbi Taobah $^{6}$, Rudy Alfiyansah ${ }^{7}$, Eldessa Vava Rilla ${ }^{8}$, Arisnawan ${ }^{9}$, Aji Lesmana ${ }^{10}$, \\ Desi Fujianti Anwar ${ }^{11}$, Restu Pangebu ${ }^{12}$, Devi Oktaviana ${ }^{13}$ \\ 1,7,8 Prodi Profesi Ners, STIKes Karsa Husada Garut \\ ${ }^{2}$ Prodi Analis Kesehatan, STIKes Karsa Husada Garut \\ ${ }^{3,4}$ Prodi S1 Keperawatan, STIKes Karsa Husada Garut \\ 9,10,11,12,13 Mahasiswa Prodi Profesi Ners, STIKes Karsa Husada Garut \\ J1. Nusa Indah No.24, Jayaraga, Tarogong Kidul, Kabupaten Garut, Jawa Barat 44151 \\ e-mail: tanpus1987@gmail.com
}

\begin{abstract}
ABSTRAK
Pergeseran pola penyakit terlihat dari meningkatnya kejadian penyakit degeneratif seperti penyakit jantung, hipertensi, diabetes dan penyakit degeneratif lainnya. Salah satu upaya yang dapat dilakukan dalam pencegahan dan pengendalian penyakit tidak menular (PTM) adalah pemberdayaan masyarakat, melalui posbindu PTM. Tujuan pengabdian masyaraka ini yaitu untuk mengetahui potensi pemberdayaan masyarakat untuk mencegah PTM, melalui posbindu. Metodelogi pengabdian ini dengan cara Pendidikan Masyarakat. Hasil observasi mengatakan bahwa program posbindu di desa sirnagalih tidak berjalan dengan baik dari $8 \mathrm{RW}$, hanya $1 \mathrm{RW}$ yang memiliki cakupan kunjungan posbindu diatas $70 \%$. Hal tersebut menyebabkan angka PTM di Desa Sirnagalih cukup tinggi, hal ini didapatkan dari data Puskesmas Cisurupan serta hasil pendataan langsung dari mahasiswa dari pintu ke pintu. Tentunya apabila hal ini dibiarkan dalam waktu yang lama dapat menjadi dampak yang buruk bagi masyarakat desa sirnagalih. Oleh karena itu screening tentang PTM pada warga perlu dilakukan. Perlu diberikan pemahaman mengenai gaya hidup yang dapat meningkatkan factor resiko yang memicu terjadinya PTM. Berdasarkan hal tersebut mahasiswa program studi Profe Ners STIKes Karsa Husada mengadakan gebyar kesehatan sebagai acara puncak pengabdian masyarakat yang berlangsung selama satu hari di desa sirnagalih Kecamatan Cisurupan. Antusias warga Desa Sirnagalih dinilai sangat baik, hal ini terlihat dari semangat warga ketika mengikuti kegiatan gebyar kesehatan. Diharapkan dengan adanya gebyar kesehatan ini dapat menjadi pemicu adanya tindakan keberlanjutan dari pihak puskesmas dan pemerintahan untuk dapat meningkatkan kinerja posbindu di desa tersebut.
\end{abstract}

Kata Kunci : Pengabdian masyarakat, PTM, Posbindu.

\section{ABSTRACT}

Shifting disease patterns can be seen from the increasing incidence of degenerative diseases such as heart disease, hypertension, diabetes and other degenerative diseases. One of the efforts that can be made in the prevention and control of non communicable diseases (NCD) is community empowerment, through integrated health post of elderly (posbindu). The purpose of this community service is to find out the potential for community empowerment to prevent NCD, through posbindu. This service method was used community education. The results of the observation said that the Posbindu program in Sirnagalih Village did not run well out of $8 \mathrm{RWs}$, only $1 \mathrm{RW}$ had a coverage of posbindu visits above 70\%. This caused the number of NCD in Sirnagalih Village to be quite higher, this was obtained from data from the Cisurupan Community Health Center and the results of direct data collection from students by door to door. So, if this is allowed for a long time it can be a bad impact on the village community Sirnagalih. Therefore, it is necessary to do screening about NCD for residents. It is necessary to provide an understanding of the lifestyle that can increase the risk factors that trigger NCD. Regarding communit survey, the students from STIKes Karsa held a health celebration as the peak of community service which lasted for one day in Sirnagalih village, Cisurupan sub-district. The enthusiasm of the residents of Sirnagalih Village was considered very good, this can be seen from the enthusiasm of the residents when participating in the health event. It was hoped that the existence of this health news can be a trigger for sustainability actions from the health center and the government to be able to improve the performance of posbindu in the village.

Keywords: communty dedication, non-communicable disease (NCD), posbindu 


\section{PENDAHULUAN}

Kesehatan Masyarakat merupakan bagian dari pembangunan nasional yaitu meningkatkan kesadaran, kemauan dan kemampuan hidup sehat bagi setiap orang agar terwujud derajat kesehatan masyarakat yang tinggi. Tetapi pada kenyataannya pelayanan kesehatan yang sampai kepada masyarakat tidak berjalan dengan baik yang diakibatkan oleh berbagai keterbatasan, sehingga kondisi kesehatan masyarakat kurang baik, kondisi ini tidak sesuai dengan yang diharapkan oleh pemerintah.

Pergeseran pola penyakit dapat dilihat dari semakin meningkatan kejadian penyakit kronis seperti penyakit jantung, hipertensi, diabetes, dan penyakit degeneratif lainnya. Data WHO, 2014 menyebutkan sekitar 68\% kematian di dunia tercatat disebabkan oleh penyakit tidak menular dan akan semakin meningkat terutama di Asia Selatan dan Afrika. Ditahun 2015, sekitar 39.5 juta atau $70 \%$ kematian di dunia disebabkan oleh penyakit tidak menular dengan empat penyebab kematian terbanyak adalah penyakit jantung, kanker, diabetes, dan PPOK (WHO 2014 \& 2015).

Hasil riset kesehatan dasar (RISKESDAS 2007) penyebab kematian utama telah terjadi pergeseran dari penyakit menular ke penyakit tidak menular. Penyakit menular menyumbang kematian sebanyak $28.1 \%$ sedangkan penyakit tidak menular (PTM) sebesar 59.5\% (Kementrian Kesehatan RI 2011). Hasil RISKESDAS tahun 2013 diketahui bahwa prevalensi PTM seperti: DM 2.1\%, penyakit jatung koroner $1.5 \%$, penyakit paru obstruksi kronis $3.7 \%$, kanker $1.4 \%$ dan gangguan akibat kecelakaan lalu lintas dan tindak kekerasan 8.2\% (Kementrian Kesehatan RI 2013). Di Indonesia tren penyebab kematian akibat penyakit tidak menular semakin meningkat dari 37\% tahun 1990 menjadi 57\% di tahun 2015 (Kementrian Kesehatan RI 2016).

Pusat Kesehatan Masyarakat (Puskesmas) adalah Unit Pelaksana Teknis (UPT) Dinas Kesehatan yang ada di Kabupaten/Kota, mempunyai tanggungjawab menyelenggarakan pembangunan kesehatan di satu wilayah kecamatan melalui pemberdayaan masyarakat sesuai dengan Kepmenkes No 128/Menkes/SK/II/2004 tentang Puskesmas dan salah satu fungsi peran puskesmas merupakan pusat pemberdayaan masyarakat dengan strategi kemitraan dengan kelompok masyarakat (Kementerian Kesehatan RI 2014).

Tujuan yang ingin dicapai dari pemberdayaan masyarakat adalah untuk membentuk individu dan masyarakat menjadi mandiri. Kemandirian masyarakat merupakan situasi kondisi yang dialami masyarakat yang ditandai oleh kemampuan untuk memikirkan, memutuskan serta melakukan sesuatu yang dipandang tepat demi mencapai pemecahan masalahmasalah yang dihadapi dengan mempergunakan daya kemampuan yang terdiri dari kemampuan kognitif, konatif, psikomotorik dengan pengerahan sumberdaya yang dimiliki oleh lingkungan tersebut. Hal ini sesuai dengan Permendagri RI Nomor 7 Tahun 2007 tentang pemberdayaan masyarakat dalam rangka penggerakan prakarsa dan partipasi masyarakat serta swadaya gotong royong dalam pembangunan didesa dan kelurahan (PERMENDAGRI 2016).

Desa Sirnagalih merupakan salah satu desa di kecamatan cisurupan yang memiliki tingkat kesadaran terkait kesehatan yang masih rendah. Luas wilayah yang sebagian besar merupakan persawahan dan tingkat pendidikan masyarakat yang sebagian besar berada pada tingkatan SD menjadikan masyarakat desa sirnagalih tidak terpapar informasi kesehatan secara 
baik. Jarak desa dengan puskesmas cisurupan juga yang tergolong jauh ( kurang lebih $10 \mathrm{~km}$ ) menjadi salah satu alasan masyarakat malas untuk pergi ke pelayanan kesehatan / puskesmas.

Posbindu PTM adalah peran serta masyarakat dalam melakukan kegiatan deteksi dini dan monitoring terhadap faktor resiko PTM serta tindak lanjutnya secara terpadu (Rahajeng, 2012). Kegiatan posbindu di Desa Sirnagalih tergolong buruk mengingat dari $8 \mathrm{RW}$ hanya $1 \mathrm{RW}$ yang memiliki cakupan kunjungan posbindu diatas 70 $\%$. Sejalan dengan "Analisis Pemberdayaan Masyarakat Sebagai Upaya Pencegahan Penyakit Tidak Menular Melalui Posbindu PTM di Kecamatan XIII Koto Kampar Kabupaten Kampar Riau" yang dilakukan oleh Tuti Restuastuti \& Ridha Restila yang menyatakan bahwa masih sedikit di daerah Kampar terbentuk posbindu PTM. Selain itu dari hasil wawancara didapatkan bahwa kunjungan masyarakat ke posyandu yang sangat rendah. Potensi yang baru dimiliki oleh daerah ini adalah terbentuknya UKBM (Upaya Kesehatan Bersumberdaya Masyarakat) yang sudah berjalan hanyalah posyandu balita dan posyandu lansia. Oleh karena itu kader kesehatan yang terlibat dalam dua kegiatan pelatihan untuk meningkatkan pengetahuan mereka tentang PTM (Tuti \& Ridha, 2018).

Dari hasil studi lapangan selama kurang lebih 50 hari selama kegiatan stase komunitas, keluarga, dan gerontik mahasiswa menemukan tingginya angka kejadian hipertensi yang tidak terkontrol pada lansia. Berdasarakan uraian tersebut mahasiswa menyelenggarakan program Gebyar kesehatan yang salah satu programnya adalah POSBINDU sehari yang didalamnya terdapat pemeriksaan kesehatan gratis mengenai tekanan darah serta adanya pemeriksaan Lab sederhana yaitu pemeriksaan asam urat dan gula darah, sebagai deteksi awal untuk upaya preventif terjadinya Penyakit Tidak Menular ( PTM ). Artikel ini menjadikan gambaran pelaksanaan kegiatan PKM ( Pengabdian Kepada Masyarakat ) yang berlangsung selama 1 (satu) hari.

\section{METODE}

Metode pengabdian ini diawali dengan survey kondisi kesehatan keluarga melalui pintu ke pintu. Setelah diperoleh data, dilakukan penyuluhan kesehatan untuk meningkatkan pengetahuan serta kesadaran warga terhadap kesehatan khusunya terkait penyakit tidak menular seperti hipertensi, asam urat, dan Diabetes Melitus pendidikan kesehatan dilakukan pada warga Desa Sirnagalih yang memiliki faktor resiko dan kurang paham dan kurang kesadarannya terhadap kesehatan. Adapun luaran kegiatan berupa pemeriksaan tekanan darah, asam urat dan cek gula darah serta penyuluhan kesehatan sesuai factor resiko yang dimilki. Adapun rincian kegiatan pengabdian masyarakat ini melalui tahapan sebagai berikut :

a. Mahasiswa melakukan SMD pada bulan Juni - Agustus 2019

b. Tim pengabdian masyrakat melakukan survey lokasi pada bulan juni - agustus 2019

c. Persiapan yang di lakukan oleh tim pengabdian kepada masyarakat untuk merencanakan kegiatan mencakup waktu, materi dan tekhnis pelaksanaan kegiatan

d. Konfirmasi dengan pihak pemerintah desa dan UPTD Puskesmas Cisurupan sebagai tempat pelaksanaan kegiatan mengenai teknis pelaksanaan, tempat sarana prasarana dan peserta

e. Pelaksaan pembukaan praktik profesi Ners dibuka oleh ketua UPTD Puskesmas Cisurupan.

f. Kegiatan pemeriksaan dilakukan di desa sirnagalih dengan jumlah 
peserta 300 orang kategori dewasa dan lansia

g. Metode ceramah digunakan untuk memberikan pengetahuan tentang Hipertensi, DM, dan asam urat.

\section{HASIL DAN PEMBAHASAN}

HASIL

Tabel 1. Distribusi Frekuensi Masyarakat Desa Sirnagalih (Per Jiwa)

\begin{tabular}{lll}
\hline Karakteristik & $\mathrm{N}$ & $\mathrm{F}(\%)$ \\
\hline Jenis Kelamin & & \\
\cline { 1 - 2 } Laki-laki & 3765 & $51 \%$ \\
Perempuan & 3571 & $49 \%$ \\
\hline Usia & 554 & $9 \%$ \\
\cline { 1 - 2 } Balita (0-5 tahun) & 1090 & $16 \%$ \\
Sekolah (5-12 tahun) & 1780 & $24 \%$ \\
Remaja (12-25 tahun) & 1219 & $17 \%$ \\
Dewasa awal (26-35 tahun) & & \\
Dewasa Akhir (36-45 & 1316 & $16 \%$ \\
tahun) & & \\
Lanjut Usia (>45 tahun) & 1177 & $18 \%$ \\
\hline Tingkat Pendidikan akhir & & \\
\hline SD & 2429 & $49 \%$ \\
SMP & 1500 & $31 \%$ \\
SMA & 891 & $18 \%$ \\
Sarjana & 63 & $2 \%$ \\
\hline
\end{tabular}

Hasil observasi selama kegiatan

PPN STIKes Karsa Husada menunjukan hasil angka kesadaran terhadap kesehatan masyarakat Desa Sirnagalih ini masih rendah. Di desa ini terdapat posyandu dan posbindu, akan tetapi yang berjalan dengan baik hanyalah kegiatan posyandu balita sedangkan posbindu tidak berjalan dengan baik. Bahkan hasil wawancara dengan warga mengatakan bahwa sebagian besar warga tidak mengetahui bahwa terdapat posbindu di desa tersebut. Tingkat pendidikan masyarakat yang sebagian besar merupakan tamatan SD (49\%) menjadikan masyarakat kurang mengerti terhadap kesehatan. Serta sumber informasi tentang kesehatan yang diperoleh dari kader kesehatan, bidan desa, serta petugas kesehatan dirasa belum maksimal. Kemudian dilakukan kegiatan SMD (Survey Mawas Diri) secara door to door dengan menggunakan kuesioner dan alat pemeriksaan sederhana seperti Tensi Meter.
Tabel 2. Distribusi Frekuensi Lansia yang Memiliki Penyakit Degeneratif (>45 tahun)

\begin{tabular}{lll}
\hline Jenis Penyakit & $\mathrm{N}$ & $\mathrm{F}$ \\
\hline Hipertensi & 472 & $40 \%$ \\
Asam Urat & 123 & $10 \%$ \\
DM & 11 & $0,9 \%$ \\
Stroke & 2 & $0,1 \%$ \\
Tanpa Keluhan & 569 & $49 \%$ \\
\hline
\end{tabular}

Didapatkan hasil bahwa sebagian besar masyarakat memiliki faktor resiko hipertensi dengan hasil pemeriksaan tekanan darah > 140/90 mmHg. Penyakit degeneratif lainnya yang di temukan berdasarkan keluhan yang diutarakan masyarakat adalah Hipertensi (40\%), DM (0,9\%), Asam urat (10\%), dan Stroke $(0,1 \%)$. dimana masyarakat yang berobat rutin ke fasilitas kesehatan tergolong sangat sedikit dan cenderung membiarkan hal tersebut karena menganggap belum menimbulkan gejala yang parah.

Hasil screening secara door to door tersebut lalu diangkat pada MMRT (Musyawarah Masyarakat RT) sehingga dirumuskan masalah bersama masyarakat. Permasalahan yang di dapatkan di setiap RT di desa ini cenderung homogen yaitu masyarakat ingin mengetahui tentang penyakitpenyakit degeneratif. Sehingga di setiap RT dilakukan penyuluhan kesehatan tentang cara mencegah terjadinya penyakit degeneratif seperti hipertensi, DM, Gout, Stroke dengan melibatkan kader, petugas puskesmas, dosen pembimbing, serta tokoh masyarakat yang ada disekitar untuk ikut andil dalam kegiatan tersebut.

Tabel 3. Distribusi Frekuensi Tingkat Pengetahuan Terhadap Penyakit Degeneratif (per KK)

\begin{tabular}{lllll}
\hline Tingkat & \multicolumn{2}{c}{ Pre-test } & \multicolumn{2}{c}{ Post-test } \\
Pengetahuan & N & F & N & F \\
\hline $\begin{array}{l}\text { Pengetahuan } \\
\text { baik }\end{array}$ & 319 & $15 \%$ & 1659 & $78 \%$ \\
$\begin{array}{l}\text { Pengetahuan } \\
\text { kurang }\end{array}$ & 1808 & $85 \%$ & 468 & $22 \%$ \\
\hline
\end{tabular}

Terjadi peningkatan tingkat pengetahuan yang sebelumnya memiliki 
pengetahuan kurang (85\%), setelah dilakukan penyuluhan menjadi baik (78\%). Hasil penyuluhan sebagian besar masyarakat dan kader memahami isi tentang penyuluhan dan diharapkan terjadinya perubahan gaya hidup dari masyarakat desa ini sehingga terhindar dari PTM di waktu yang akan datang. Semua permasalahan yang ada di RT kemudian diangkat pada MMD (Musyawarah Masyarakat Desa).

Pada tahap awal kegiatan dilakukan terlebih dahulu musyawarah masyarakat desa (MMD) sehingga di sepakati di adakannya gebyar kesehatan sebagai acara puncak berakhir nya PPN STIKes Karsa husada garut di Desa sirnagalih. Kegiatan gebyar kesehatan tersebut meliputi senam sehat, pemeriksaan kesehatan gratis, jalan sehat, sunatan masal, pagelaran budaya setempat (pencak silat).

\section{Untuk}

pemeriksaan

kesehatan gratis sebagai bentuk pelaksanaan Posbindu PTM sehari, calon peserta dibagi kupon terlebih dahulu. Kegiatan dilanjutkan dengan pemeriksaan tekanan darah, gula darah dan asam urat kepada peserta yang sudah memiliki kupon.

Tahap selanjutnya ialah pemberian materi penyuluhan kesehatan kepada peserta disesuaikan dengan keluhan dan hasil pemeriksaan yang mengarah pada penyakit seperti hipertensi, asam urat dan DM. pelaksana kegiatan ini merupakan kolaborasi antara mahasiswa Ners, Dosen STIKes Karsa Husada dan Puskesmas Cisurupan.

Secara umum peserta sangat antusias terhadap kegiatan gebyar kesehatan ini. Hal ini tidak terlepas dari ketertarikan peserta untuk lebih menjaga kesehatan setelah diberi pengetahuan dan pemahaman tentang penyakit tidak menular.

\section{PEMBAHASAN}

Pemberdayaan masyarakat adalah suatu strategi yang digunakan dalam pembangunan masyarakat sebagai bentuk upaya untuk mewujudkan kemampuan dan kemandirian dalam kehidupan, bermasyarakat, berbangsa dan bernegara (pasal 1, ayat 8) (PERMENDAGRI 2016). Pemberdayaan masyarakat merupakan suatu upaya dalam menumbuhkan kesadaran, kemauan, kemampuan masyarakat dalam pengedalian PTM dan faktor risikonya. Dalam hal ini diharapkan masyarakat mampu dan melakukan pemantauan faktor risiko PTM melalui kegiatan berbasis masyarakat.

Salah satu strategi pengendalian PTM yang efisien dan efektif adalah dengan cara melakukan pemberdayaan masyarakat dan peningkatan peran serta masyarakat dalam setiap kegiatan yang dilakukan. Kasus PTM sebenarnya dapat dicegah dengan mengendalikan faktor risiko, yaitu gaya hidup yang meliputi kebiasaan merokok, diet yang tidak sehat, kurang aktifitas fisik dan konsumsi makanan beralkohol. Selanjutnya juga merupakan faktor risiko PTM adalah obesitas, stress, hipertensi, hiperglikemi, hiperkholesterol serta menindak lanjuti secara dini faktor risiko yang ditemukan melalui konseling kesehatan dan segera merujuk kefasilitas pelayanan kesehatan dasar (Irwan 2016; Kementrian Kesehatan RI 2012 \& 2013).

Salah satu upaya untuk mengendalikan PTM adalah pemberdayaan serta peningkatan peran serta masyarakat melalui kegiatan Posbindu PTM, karena Posbindu PTM merupakan wujud peran serta masyarakat dalam melakukan kegiatan deteksi dini, pemantauan faktor risiko PTM serta tindak lanjut dini yang dilaksanakan secara terpadu, rutin dan periodik (Astuti et al. 2016). 
Dari hasil survey menunjukan bahwa angka kesadaran terhadap kesehatan masyarakat Desa Sirnagalih ini masih rendah. Di desa ini terdapat posyandu dan posbindu, akan tetapi yang berjalan dengan baik hanyalah kegiatan posyandu balita sedangkan posbindu tidak berjalan dengan baik. Bahkan hasil wawancara dengan warga mengatakan bahwa sebagian besar warga tidak mengetahui bahwa terdapat posbindu di desa tersebut. Tingkat pendidikan masyarakat yang sebagian besar merupakan tamatan SD menjadikan masyarakat kurang mengerti terhadap kesehatan. Hal ini sejalan dengan penelitian dari Dina \& Naning (2018) yang menyatakan bahwa pendidikan suatu kelompok mempengaruhi nilai dari pengetahuan kelompok tersebut. Pengetahuan sangat erat kaitannya dengan pendidikan dimana diharapkan seseorang dengan pendidikan tinggi. Orang tersebut akan semakin luas pula pengetahuannya. Tetapi selain dari pendidikan formal, pengetahuan tersebut juga dapat diperoleh dari pendidikan informal (Dina \& Naning, 2018).

Pendidikan

berarti

bimbingan yang diberikan seseorang terhadap perkembangan orang lain menuju ke arah cita-cita tertentu yang enentukan manusia untuk berbuat dan mengisi kehidupan untuk encapai keselamatan dan kebahagiaan. Pendidikan diperlukan untuk mendapatkan pengetahuan, misalnya hal menunjang kesehatan, sehingga dapat meningkatkan kualitas hidup. Pada umumnya makin tinggi pendidikan seseorang akan makin mudah seseorang menerima pengetahuan (Wawan \& Dewi, 2010).

Selain pendidikan perlu diperhatikan juga sumber informasi layanan kesehatan. Di desa sirnagalih sumber informasi berasal dari kader kesehatan, bidan desa, dan petugas puskesmas. Hasil observasi mahasiswa menemukan bahwa pemberian informasi kepada masyarakat dinilai belum maksimal. Khususnya terkait posbindu PTM yang ada di desa ini, sebagian besar masyarakat tidak mengetahui tentang keberadaan posbindu di desa ini. Informasi akan memberikan pengaruh pada pengetahuan seseorang. Meskipun seseorang memiliki pendidikan yang rendah tetapi jika ia mendapatkan informasi yang baik dari berbagai media misalnya tv, radio, surat kabar, atau orang di sekelilingnya. Maka hal itu dapat meningkatkan pengetahuan seseorang (Wied Harry A, 2007). Informasi adalah salah satu organ pembentuk pengetahuan dan memegang peranan besar dalam membangun pengetahuan. Semakin banyak banyak seseorang memperoleh informasi, maka semakin baik pula pengetahuannya, sebaliknya semakin kurang informasi yang diperoleh, maka seakin kurang pengetahuannya (Suryani, 2007).

Dengan diadakannya Gebyar

Kesehatan oleh mahasiswa ini diharapkan dapat menjadi upaya promotif dan meningkatkan kesadaran masyarakat terhadap pentingnya kesehatan dan mencegah terjadinya PTM di waktu yang akan datang. Salah satu bentuk stimulasi terhadap masyarakat yaitu dengan kegiatan posbindu PTM satu hari yanng berisi tentang pemeriksaan lab sederhana serta penyuluhan kesehatan dan edukasi gaya hidup yang sehat. Edukasi atau penyuluhan yaitu untuk menyebarkan informasi atau merupakan penyebarluasan informasi dari satu pihak ke pihak lain khususnya masyarakat dalam proses pemberdayaan, di mana diharapkan dapat menumbuhkan kesadaran kritis, menumbuhkan perubahan sikap, dan perilaku masyarakat. Hal ini sudah dilakukan dan sudah terbukti dari hasil olahan data yaitu adanya peningkatan pengetahuan yang diharapkan dengan pengetahuan yang meningkat ada perubahan perilaku 
masyarakat terhadap pencegahan dan penanggulangan penyakit tidak menular (Notoadmodjo 2007).

\section{KESIMPULAN}

1. Angka kesadaran masyarakat terhadap kesehatan masih rendah.

2. Pelaksanaan posbindu di Desa Sirnagalih tidak berjalan dengan baik

\section{SARAN}

1. Kegiatan pemeriksaan kesehatan ini tentunya dapat menjadi masukan bagi puskesmas cisurupan agar kegiatan posbindu di desa sirnagalih ini lebih diperhatikan.

2. Diharapkan adanya tindakan keberlanjutan dari pihak puskesmas dan pemerintah untuk membentuk posbindu PTM.

\section{DAFTAR PUSTAKA}

A, Wawan dan Dewi. 2010. Teori dan Pengukuran Pengetahuan, Sikap, dan Perilaku Manusia. Yogyakarta : Nuha Medika.

Apriadji. 2007. Pengetahuan Perilaku. Jakarta : PT Penebar Swadaya

Dina, Z, F \& Naning, F, R. 2018. Pemanfaatan Pos Pembinaan Terpadu (POSBINDU) Penyakit Tidak Menular (PTM) Pada Penderita Hipertensi. Jurnal Ners dan Kebidanan, 5(1), 20-28

Kementerian Kesehatan RI. 2011. Pusat Promosi Kesehatan. Rencana operasional promosi kesehatan dalam pengendalian penyakit tidak menular. Jakarta.

Kementrian Kesehatan Indonesia. 2012. Petunjuk Teknis Pos Pembinaan Terpadu Penyakit Tidak Menular (Posbindu PTM). Jakarta.

Kementrian Kesehatan Indonesia. 2013. Buku Pintar Kader Petunjuk Pengukuran Faktor Risiko di Posbindu PTM. Jakarta.

Kementrian Kesehatan Indonesia. Kepmenkes

No
128/Menkes/SK/II/2004 tentang Kebijakan Dasar Puskesmas. Retrieved from www.hukor.depkes.go.id/hukor/0/ 2014/14).

Kementrian Kesehatan RI. 2013. Riset kesehatan dasar 2013. Jakarta

Kementrian Kesehatan RI. 2016. Gaya Hidup Penyebab Kematian Kian Dominan. Retrived from http://pptm.depkes.go.id/cms/fron tend $/ \mathrm{p}=$ infoslide $\& \mathrm{id}=43$

Notoadmodjo S. Promosi Kesehatan dan Ilmu Perilaku. Jakarta; Rineka Cipta, 2007; 22-26

PERMENDAGRI RI Nomor 16 tahun 2016 Pedoman Penelitian \& Pengembangan di Kementerian Dalam Negeri \& Pemerintahan Daerah.

Rahajeng, S, M. 2012. Petunjuk Teknis Pos Pembinaan Terpadu Penyakit Tidak Menular. Jakarta : Kementrian Kesehatan RI.

Riset Kesehatan Dasar (RISKESDAS). 2007. Laporan Nasional, Badan Penelitian \& Pengembangan Kesehatan, Department Kesehatan, Republik Indonesia.

Suryani. 2007. Psikolog Kognitif. Surabaya : Dakwah Digital Press.

Tuti, R \& Ridha, R. 2018. Analisis Pemberdayaan Masyarakat Sebagai Upaya Pencegahan Penyakit Tidak Menular Melalui POSBINDU PTM Di Kecamatan XIII Koto Kampar Kabupaten Kampar Riau. Asian Journal of Environment, History and Heritage, 2(1), 51-58.

World Health Organization. 2014. Noncommunicable diseases country profiles 2014 .

World Health Organization. 2015. Global Health Observatory (GHO Data): NCD Mortality and Morbidity. Retrieved from http://www.who.int/gho/ncd/mort ality_morbidity/en/ 